\title{
HDAC8 Gene
}

National Cancer Institute

\section{Source}

National Cancer Institute. HDAC8 Gene. NCI Thesaurus. Code C113605.

This gene is involved in the modification of histone proteins. 